\title{
CONCEPT, DEFINITION AND CHARACTERISTICS OF THE MONEY LAUNDERING PHENOMENON
}

\author{
Natasha Georgieva \\ University MIT, Faculty of Security, Skopje, North Macedonia \\ natashageorgievaivanovska@gmail.com
}

Professional Paper

10.5937/jouproman8-26220

\begin{abstract}
Money laundering is becoming an increasingly pressing issue for the scientific and professional public. Financial crime, no matter what form it takes, has the sole motive or purpose of the perpetrators, the acquisition of illegal property by making very small efforts, and most often it is the exploitation or abuse of work responsibilities, function, duty or power.

From the previous knowledge and previous researches, one gets the impression that this is a very current problem, which leaves negative consequences and traces in people's daily lives and of course interest in society for overcoming it. Today, we are witnessing numerous debates and lectures, ie activities undertaken by the organizations to overcome the situation. At the same time, it seems that the efforts made to eliminate the factors for the occurrence of the problem are insufficient, so while theoretical elaborations on the problem are being carried out, the pages of the newspapers are being filled and they are breaking news for all media.

Experiences in the field of combating the phenomenon of money laundering and prevention so far, despite the huge efforts, show that the desired results have not been achieved. Such a thesis is confirmed by several arguments and statistics that go in the direction that not only has the number of this crime not decreased, but that it is increasing rapidly. But the "dark figure" of this crime is also worrying, with the abuse of bank officials in the process of preventing or investigating money laundering, the number of unsolved cases being high, the impact of corruption taking its toll.
\end{abstract}

Keywords: crime, money laundering, society, negative behavior, characteristics, typology.

\section{Introduction}

Money laundering is a criminal activity that in recent years has received increasing attention from the scientific and professional public, primarily in order to find possible solutions to combat this phenomenon, which is a danger to the national and global financial system. The infiltration of criminal money, or illegal money, causes currency instability, inflation and economic instability.

Money laundering is illegal, increasingly used sanctioned activity, by falsifying business-financial documentation or performing other actions in order to present the money gained from illegal activities as legally acquired profit from economic activities (Mrsevic, 1992).

Money laundering involves the process of converting income from illegal activities into funds that originate from seemingly legal sources without revealing their true source, nature or ownership. Money laundering can be defined as "the use of money derived from illegal activities by concealing the identity of individuals who have received it and turning it into funds that appear to originate from legal sources" (Medinger, 2009). 
Money laundering is a problem of the past, present and future because criminals are criminally acting to gain illegal property, which they intend to retain, to enjoy the "fruits" of crime, but there is always a "fear of discovering and taking away" criminally acquired returns. That is why criminals in any kind of criminal activities that result in the acquisition of illegal property gain require methods, ways and means to "shelter" that benefit, transformation into another type of property and of course "security from confiscation" (Nikoloska, 2015).

Sophisticated techniques used to legalize "dirty" money further complicate matters. Such sophisticated techniques can involve several different types of financial institutions, primarily banks, savings banks, insurance companies, fund management companies, but also other non-financial entities such as: real estate traders, lawyers, notaries, financial advisors, through the use of several different financial instruments and other products. Money launderers adapt to the situation and use both traditional and sophisticated money laundering techniques, but always use the method of corruption of authorized persons in financial and nonfinancial institutions in order to avoid reporting suspicious transactions or counseling for splitting transactions to avoid reporting transactions. There are great opportunities to avoid reporting suspicious transactions where the subjective characteristics and characteristics of the authorized persons in terms of recognizing the "money launderers" and the legal solutions for "duty in recognition" are expressed.

Money laundering is the process of making illegally obtained returns (ie, "dirty money") appear legal (ie, “clean"). Typically, this consists of three steps: placement, layering, and integration. First, illegitimate assets are secretly introduced into a legitimate financial system. Then, the money is moved around to create confusion, sometimes by transferring through numerous accounts. Finally, by integrating into the financial system through additional transactions, "dirty money" appears to be "clean". Money laundering can facilitate crimes such as drug trafficking and terrorism, as well as negatively affect the global economy (http://www.fincen.gov/news_room/aml_hi story.html).

Money laundering as an accompanying phenomenon of criminal activity is present in countries around the world, it is committed in different ways and manifests itself in different forms. With money laundering operations, "launder" money obtained through criminal activity due to its "dirty" origins in order to show that it was acquired legally and used as "clean" in legal economic and financial flows. The activities of acquiring "dirty" money are generally incriminated in specific criminal offenses, which, if not detected and the criminal responsibility of the perpetrator is not proven, ie confiscates the illegally acquired property gain, leads to a situation where certain entities are in a situation where that money through the process of "laundering" they are legalized through banking, financial and other transactions (Boskovic, Jovicic, 2002).

Preventing money laundering is an activity of great importance, especially at the international level. Given that the use of banks for criminal activities is common in the international financial market, significant efforts are being made internationally to control and limit this phenomenon. 
Numerous examples of international activity in this field can be listed, with the most important being the work of the Financial Action Task Force (FATF), formed by the G-7 member states at the summit in Paris in 1989 and the work of the Basel Committee on Banking Supervision. One of the first goals of the Financial Action Task Force is to define the Recommendations that determine the measures that countries should take to establish effective programs to prevent money laundering. In June 2003, a revised text of the Recommendations issued by the FATF was published, referring to both the fight against money laundering and the fight against terrorist financing, known as the Forty-Nine plus nine special recommendations. It should be noted that these recommendations have been accepted by the International Monetary Fund and the World Bank as international standards for the prevention of money laundering and the fight against terrorist financing.

The money laundering process is a complex process, it is a criminal activity in which at least two people or perpetrators are involved, and that is the money launderer (client) and the laundry - the subject. However, according to the definitions of money laundering, this process does not end with placing the money of the money launderers in the entities, but that process is a process of moving the money by transferring it to their integration or use. In this process, several participants are involved, most of whom are in banks as financial institutions where legal entities and individuals have accounts on which they are placed and through which money is transformed or extracted as laundered or legalized money.

\section{The concept and definition of money laundering}

The term "money laundering" is used to describe the criminal activities used by criminals in order for the proceeds of crime, which are mainly in the form of cash, to be "cleared" so that they can then be used again by criminals as legal income. Criminals are taking a series of actions to cover up the proceeds of their criminal activity. Although money laundering has long been considered a marginal problem, after the expansion of the drug trade, it has become an integral part of any serious criminal activity. Money laundering consists of a series of financial operations (deposits, withdrawals, transfers, etc.) that turn "dirty" money from crime into "clean" money, which can be used for legitimate business activities. In fact, "cleaned" dirty money is "recycled" through legitimate businesses, and from there they enter the legitimate market and spread throughout the economy (National Strategy for Combating Money Laundering and Terrorist Financing, 2005).

The money laundering phenomenon is a phenomenon directly related to the activities of transnational criminal organizations, the number of which cannot be determined with certainty today. Criminal activities are characterized by diversity and focus on "conquering" enormously high financial gains.

The number of definitions, according to which the content of the money laundering phenomenon can be successfully captured, cannot be determined with precision. 
When defining the phenomenon of money laundering, globally, one always starts from one basic, starting point, but also the most appropriate definition for organized crime, as organized participation of several persons in a criminal offense, ie: "committing criminal offenses by a criminal association due to making a profit and (or) power, by using violence or by using a special position in society, by reducing the risk by engaging in legal economic, political and other activities and by creating a system of protection in advance from persecution"(Kambovski, 2011). Hence, it can be concluded that money laundering is a complex process or a covert, sophisticated and profitable activity whose "help" successfully creates wealth, ie acquires direct or indirect financial benefit or some other kind of material benefit. It is important to note that this activity always takes place in the field of economics, finance and high technology, through which money transactions are made. Using financial institutions, "money laundering" is an activity of an accessory nature, because as a part, ie as a link in the overall "chain of crime", it is only a continuation of a previous criminal activity.

Money laundering could generally be defined as a procedure for concealing the existence, illegality of sources and use of proceeds of criminal activity, ie. their legalization. Fraud is the center of the entire money laundering procedure through the false display in front of the competent institutions of the origin of the property, both legally and its use as legally acquired income (Banovic, 2002).

Money laundering is illegal, increasingly used sanctioned activity, by falsifying business-financial documentation, or performing other actions in order to make money gained through illicit activities displayed as legally acquired profits from economic activities (Mrsevic, 1992).

According to the Larousse encyclopedia, money laundering is defined as "the application of a series of operations over funds, after which their smuggling and illegal origin may be concealed" (Nikolovski, 2014). So, this is a phenomenon through which the international branches of large banks, money earned illegally and outside the tax and official financial flows (usually from the black stock market, blackmail, theft, drug trafficking, cigarettes or weapons, prostitution, racketeering, etc.) should formalize and return them to the legal flows through anonymous bank accounts, purchase agreements, capital investment or in other ways.

Money laundering under the Law on Prevention of Money Laundering and Other Proceeds from Crime and Financing of Terrorism is defined as: "Replacement or transfer of property in order to conceal or conceal the illegal origin of that property; concealment or alteration of the true nature, location, use and transfer of property acquired illegally; acquisition, possession or use of property by any person who is known or may have known that such property originates from criminal activities and the commissioning, distribution and use of illegally acquired money to perform a legally permitted activity or to acquire property legally" (Law on Prevention of Money Laundering and Terrorist Financing, 2014).

As a widespread international phenomenon that has been on the rise in recent years, criminal money laundering can particularly hit transition economies that offer significant opportunities for foreign investment. 
Financial controls, both in the banking and non-banking sectors, are often less stringent in these countries than in others. This makes transition countries particularly vulnerable to money laundering operations. Taking into account all the various illegal activities, including money laundering by organized crime groups, in some of these countries and in some cases, their alleged infiltrations into the overall national economies, it is in the vital interest of these countries to create and to maintain a credible financial system capable of detecting, preventing and controlling money laundering.

\section{Defining the term money laundering}

There are authors who believe that the term "money laundering" was first used in the 1970s or later, and the literature suggests that the phenomenon began in the 1930s in the United States, when Chicago criminals made money through prohibited actions where they have shown through the turnover of the newly opened laundry rooms. It is believed that hence the term "laundry" used in connection with this phenomenon, which through the processes through which it is realized, seeks to transfer dirty yields creates in clean funds (Batkovski, 1996).

The emergence of the term "money laundering" in all the mentioned cases is related to organized criminal activities and illegally obtained proceeds of crime. Money laundering is seen as a process of conversion or laundering of property, which is known to have been acquired after route of serious criminal activity in order to conceal its origin.

One of the most common and simplest understandings, and according to some authors, the simplest definition of the term "money laundering" is that it is the conversion of "black money into green" (Williams, 1997). This understanding, which does not cover all aspects of the phenomenon, nevertheless provides an approximation to the essence of the problem for those who first encounter the term "money laundering". The meaning of the term "money laundering" can be understood simply as the movement of money away from where it is vulnerable to seizure and confiscation, ie in areas where it is safe. Namely, the seizure of real estate is not uncommon in cases of money laundering, because the purpose of a number of money laundering schemes is to gain material benefits, ie houses, apartments, buildings, companies and so on. This confiscation is not only much more complicated, but is also regulated by certain special procedures (Medinger, 2009).

It is especially important to keep in mind that money laundering is a process that is often very complex, and money launderers use a variety of techniques to achieve their goals. In an effort to facilitate the discovery and analysis of this phenomenon, the three-part framework has increasingly been used in practice, with the help of which the money laundering process is schematically presented as a three-stage process (Ignjatovic, 2010):

$\checkmark$ placement - where cash acquired from criminal activity (eg drug trafficking) is placed in financial institutions or used to buy goods;

$\checkmark$ concealment - a phase that contains the first attempt to conceal or disguise the source of the origin of the funds, and

$\checkmark$ integration - a phase in which money is integrated into the legitimate economic and financial system and assimilated with other goods in that system. 
Money laundering techniques are innumerable, diverse, complex, subtle, and secretive, and to meet the basic needs of money launderers, they all have common characteristics, including (International Narcotics Strategy Report, 1988):

$\checkmark$ the need to conceal real property and the origin of yields;

$\checkmark$ exercising control over criminal proceeds, and

$\checkmark$ changing the form of yields.

Having in mind the concept and nature of the money laundering process, the goals of criminals and money launderers and the use of various techniques to criminalize criminal proceeds should be protected from the actions of law enforcement agencies responsible for combating crime, in international documents and in National legislation has made a number of attempts to define the term money laundering, which would facilitate the fight against this phenomenon.

The UN Convention against the Illicit Trafficking in Narcotic Drugs and Psychotropic Substances (Vienna Convention), adopted in November 1988, defines the term money laundering, which forms the basis of definitions contained in other international documents and national legislation in the field of criminalization. washing or possessing drug yields. The Convention also provides for the proper sanctioning and enumeration of these incriminations in the ranks of extradition offenses. This is the first international document of global proportions to implement the international consensus of the 1980s on the criminalization of money laundering and the confiscation of criminal proceeds, which covers both issues.

The latest international agreement defining the money laundering phenomenon is the 2000 Convention against
Transnational Organized Crime, known as the Palermo Convention. The provisions of this Convention are also based on the provisions of the Vienna Convention. In addition, it is recommended that Member States anticipate all "serious crimes" as previous offenses, such as those defined in the Convention, as well as participation in an organized crime group, corruption and obstruction of justice.

More definitions of this term can be found in the documents published by international organizations, institutions and services, whose task is to prevent and combat the phenomenon of money laundering. Most of these definitions are based on international documents and contain almost the same elements, and the following definitions can be singled out as the most comprehensive and widely accepted.

The definition in the UK Financial Sector Guidelines states: "Money laundering is a process used by criminals to cover up the origin and ownership of proceeds from their criminal activity. If successfully implemented, it allows them to control these returns, with the ultimate goal of providing legitimate coverage for the source of returns" (Guidance For the Financial Sector, 1997).

The definition provided by the US Customs Service, in their material submitted to the G-7 group, according to which money laundering is:"A process through which profits that are believed to be derived from criminal activity are transported, transferred, transformed, converted or incorporated into legal funds in order to conceal their origin, source, movement or ownership. The purpose of the money laundering process is through illegal activities to allow these funds to appear as legal" (Williams, 1997). 
The most common definition in the United States, which refers to money laundering, is "methods used to launder money obtained in a dishonest manner, so as not to reveal their illegal origin". More specifically, money laundering involves a variety of methods by which criminals hide the source, origin, and ownership of illegally obtained money by participating in transactions that externally demonstrate that the assets have a legitimate source (Brashir, 1995).

The presented definitions cover the effort to conceal property and the origin of money, presented as a process in which criminals apply a variety of methods to allow illegal proceeds to appear as legal and to be incorporated into the legal economy. The main motive for undertaking these complex operations is the fact that the property can open the questions of origin.

However, what can be noticed in these definitions is the lack of explicitness regarding another basic component of money laundering, ie that the profits gained through criminal activity should be placed out of the reach of law enforcement services, and thus and protect against seizure or confiscation. The basis for the inclusion of this element in the definitions of the term money laundering is in the definition enshrined in Article 3 (b) (i) of the Vienna Convention, which states: "in order to conceal or remedy the illegal origin of the property or to help any person involved in the commission of such an offense or criminal offense to avoid the legal consequences of such an act".

The latest efforts by the international community to criminalize money laundering from all forms of crime, efforts to provide maximum opportunities for the detection of crimes and their perpetrators, as well as more concerted efforts to improve confiscation opportunities, are widely accepted and implemented. in national legislation, they impose the need to expand the definitions of money laundering with the element of avoiding the legal consequences of such an action. Therefore, it is considered that the most comprehensive definition of the term money laundering would be the following (Ignjatovic, 2010): “A process through which profits that are believed to be derived from criminal activity are transported, transferred, transformed, converted or incorporated into legal financial flows, in order to conceal their origin, source, movement or ownership, to allow these assets to appear as legal, and persons involved in criminal activities to avoid the legal consequences of such action".

The elements of this definition include: the concept of criminalizing money laundering from any kind of criminal activity; the complexity and subtlety of the money laundering process; the techniques and methods used in this process and the ultimate goal - the emergence of criminal proceeds as legal and the avoidance of the legal consequences of criminal acts.

\section{Historical legal perceptions of money laundering}

Although the phenomenon of money laundering is seen as a relatively new criminal phenomenon, the term "money laundering" is one of the more oldfashioned terms. It is believed that this coinage was created and used for the first time by members of the American law enforcement agencies and that the term was very popular during the Watergate affair in the mid-1970s (Gilomre, 1995). 
Other authors (Williams, 1997)), consider the godfather of modern money laundering to be Meyer Lensky, who transferred money across the coast to protect them from police and tax authorities, while the term in the judiciary or in a legal context is also for the first time used in 1982 in the United States for investment and the mafia in legal businesses (Frchkovski, 1995). Since then, the term has become widely accepted in national and international level, and extensively used in international documents.

The process of implementing the relevant legal provisions in the national legislations did not start with the determination of the term that was considered the most appropriate in the presentation of this criminal process. In the United States, for example, the phenomenon of "money laundering" was first incorporated into the Banking Secrecy Act of 1970, while the act of "money laundering" was first criminalized in 1986 with the passage of the Money Laundering Control Act. In the UK, the modern legal framework for money laundering related to drug crime has been in place since the adoption Drug Traffiking Offences Act of in 1986 (Gilomre, 1995).

The term "money laundering" comes from the fact that the US mafia has been running a chain of laundry (rooms) workshops since the 1930s, when gangsters and mobsters made large sums of cash from extortion, prostitution, gambling or selling alcohol.

Al Capone was convicted in 1931 of tax evasion, a year when criminals began to think more seriously about how to hide their illegally earned income. Mayer Lansky, known as a mafia accountant worried about not experiencing the same fate as his boss Capone, is beginning to explore the possibilities of concealing money and has not long since discovered the benefits of numbered Swiss accounts. The idea was also developed by Leslie Lansky, known as the first money launderer who, using "Swiss" capabilities, established the first money laundering technique known as the "loan repayment" concept.

Finally, since the 1980s, concerns have grown about the negative consequences of investing significant amounts of criminal origin in the legal economy and the degree of power and control that result from it. In the 1980s, money laundering in the context of drug trafficking attracted special attention. Why? In the United States and Western European countries, drug trafficking has caused major problems that have required a major and vigorous response from states and its organs. One of the ways to solve this problem was to prepare regulations and build institutions with an activity aimed at depriving criminals of illegally earned income (Manual for Implementing Measures and Actions to Prevent Money Laundering and Terrorist Financing by Subject Side, 2010).

Statistics also show the magnitude and severity of money laundering. Drug trafficking and organized crime are not only international in nature, they are also extremely lucrative. And while the difficulties of accurately determining the amounts generated by such activities are generally known, all data suggest that those amounts are enormously high. World experts estimate that the amount of money laundered in the world could range between 2 and 5 percent of the world's gross domestic product, from $\$ 790$ billion to $\$$ 1.5 trillion. 
Such a figure certainly demonstrates the seriousness of this problem, for which every democratic country takes appropriate steps and measures to resolve it.

\section{Characteristics of money laundering}

In the process of transforming dirty money into clean, two elements are necessary, a "laundry" and a "money launderer".

The "laundry" is usually part of the standard financial system (banks, savings houses, exchange offices, insurance companies, brokerage houses, real estate agencies, casinos, etc.), which most often do not even know that they are part of the complex process of cleaning the dirty money.

The "money launderers" are the direct perpetrators of crimes that try to give legitimacy to the acquired wealth.

It is important to know that money laundering is a process, often a very complex one, but not an individual one. The complex process of "money laundering" can be divided into three stages (Ashworth, 2010):

$\checkmark$ in the first phase, the money is placed (inclusion in the system);

$\checkmark$ the second phase covers the process of severing the connection with the source of funds (concealment of traces), and

$\checkmark$ the third phase is the integration with which the perpetrator of the crime takes the money laundered.

The placement phase is the first phase of the introduction of "dirty" money into the world of legitimacy. In doing so, various techniques and methods are used, from buying goods and services to depositing money in the financial system that mask the real depositor through several secondary transactions.

In order to reduce the risk at this stage, the operation "smurfing" or decomposition of the amount is most often used, thus the amount of laundry is divided into smaller amounts, usually between different individuals or companies and then introduced into the legitimate system. Once the principal amount has been divided into smaller amounts, it can be used to buy financial instruments, use them as bank deposits, or place them in legitimate cash, such as various clubs, restaurants, and casinos. For the criminal or the money launderer, the placement stage is the most risky.

With the completion of the placement phase, the phase of "layering" begins, ie concealment, which aims to cover the trace of the illegitimate assets by interrupting the documentary trace that was created in the phase of the placement. As in the phase of placement in the phase of concealment, various techniques and methods are used to conceal the source of funds through the formation of fictitious companies in offshore jurisdictions, further through multilayered transfer and return of funds, through fraudulent transactions and fictitious and inflated invoices or by investing money in international financial markets in shares or other securities. In the second or phase of concealment, a series of conversions or movements of the assets are performed in order to distance them from the source. The concealment of the funds is aimed at obstructing the control of the origin of the assets and providing anonymity, ie concealing the identity of the end user of the assets. 
In the last phase of "integration", if the previous two phases are successfully completed, the money gets full legitimacy and the perpetrator can use it smoothly and without risk, but this time as "clean" money.

So the goal of integration is to return the money laundered to the owner who further uses it for his own needs to invest in real estate, luxury goods or make several different business deals.

The way money launderers work is as follows (Ignjatovic, 2010):

$\checkmark$ Do not attract attention.

$\checkmark$ Always have a cover for your actions and

$\checkmark$ Work through a number of intermediaries.

Furthermore, there are also a several reasons why criminals launder money. These include:

$\checkmark$ Hiding wealth: criminals can hide illegally acquired wealth in order to avoid seizure by the competent state authorities.

$\checkmark$ Avoidance of criminal prosecution: criminals avoid criminal prosecution by the authorities by distancing themselves or distancing themselves from illegal means.

$\checkmark$ Tax avoidance: criminals can avoid paying tax on income from assets.

$\checkmark$ Increasing profits: criminals can increase profits by reinvesting illegal funds in businesses and

$\checkmark$ Legitimacy: criminals can use legalized means to start a business and ensure its legitimacy.

There are serious economic and social consequences of committing the crime of money laundering. These include the following:

$\checkmark$ Undermining financial systems: money laundering expands the black economy, undermines the financial system and raises the issue of credibility and transparency.

$\checkmark$ Expansion of crime: money laundering encourages criminals because it enables efficient use and distribution of their illegal assets and

$\checkmark$ Reduction of revenues and control of money laundering: the government reduces tax revenues, which prevents a better life for citizens (health, social policy, infrastructure, etc.), and at the same time weakens the control over the economy.

Money laundering as a global phenomenon is associated with certain activities such as: drug and arms trafficking, human trafficking, prostitution, tax evasion, abuse of office, corruption, etc. The amount of money generated by drug trafficking, arms trafficking and other illegal businesses is very large and most often institutionalized by drug dealers and criminal groups through legitimate activities. Often these are restaurants, bars, casinos and other types of gambling businesses, taxi companies and various other seemingly harmless activities in which cash is traded. To finance these activities, funds are often used that are obtained illegally, and the profit is directed to terrorist activities.

Money laundering is also closely linked to the evasion of public duties by the state. Therefore, in the fight against money laundering, close cooperation is needed between the services in charge of this area and the tax authorities, in order to increase tax control of people who are exposed to spending larger amounts of money (buying houses, cars and other types of luxury goods) and determining whether those revenues have been reported and whether tax has been paid on them. 
Drug dealers and other criminal organizations have developed a series of highly specialized techniques and methods designed to remove "dirt" from the money and put it out of the reach of law enforcement agencies. Using a variety of techniques, they are able to take advantage of its existence. on a global financial system to achieve their ultimate goals and turn illegal returns into legal ones.

The peculiarities of the global financial system that affect money laundering are numerous, which is why there is a constant struggle between money launderers - seeking the least resistance and the lowest risk - and government and law enforcement agencies seeking to detect, obstruct and prevent the circulating of the laundry circle. As a result, the money laundering industry is very innovative and highly dynamic. Customers are constantly looking for new ways to circumvent regulations and minimize the likelihood that their criminal record will be seized. This does not mean that they find methods that are superior to the previous ones. They simply make every effort to expand the repertoire of available and effective options. Successful methods are repeated elsewhere, and even patterns that were once discovered are sometimes used again, in other locations, or with minor modifications (Gilomre, 1995).

Faced with this problem, countries and the international community seek to analyze and typologize trends and money laundering techniques to find an answer to the question of setting appropriate response mechanisms. The purpose of the analysis and typology is to create an opportunity for experts within law inforcement agencies and regulatory bodies to discuss the latest trends in money laundering and the threats they pose, in order to identify and establish effective countermeasures.

\section{Emerging forms and schemes of money laundering}

The criminal offense of money laundering is included in the so-called new forms of organized crime, with which the money and / or property gain gained by committing criminal offenses infiltrates legal businesses, ie payment operations, banking and financial operations, as well as other forms of economic operation. The focus of injustice is on the inclusion of criminal proceeds or illegally acquired money in legal economic flows.

The emerging forms of money laundering, which are determined by the previous criminal offenses in terms of finding a way to launder the money gained from the previous criminal activity, are realized according to a previously planned and well-developed scheme. Depending on the type of previous crimes, it is planned and works with an appropriate money laundering technique. The difference in the emerging forms of money laundering is whether the previous criminal offenses are economic - financial, where fictitious business documentation is used for money laundering or other classic criminal offenses that have resulted in illegal acquisition. Illegally acquired money or other illegally acquired property is brought into the economic and financial flow in order to transfer the profits from the illegal, criminal "black business" to the "legal financial world". Most of the criminal proceeds from drug dealers or human trafficking crimes, as well as other forms of violent crime, invest "criminal money" in buying shares in wellestablished companies or corporations and thus incorporate into the business world. 
Double business is also known, a combination of criminal and legal business where criminals, in addition to legally registered companies and businesses, criminally operate with "black businesses" better known as "black economy" related to goods that are prohibited for trade - drugs, weapons, people. Working with the legal business serves as a "screen" for illegal activities, and by using some degree of corruption, they manage to portray the money earned from crime as turnover from the legal business. In this way, they manage to expand their business faster and become economically strong, and economic power is an important precondition for gaining political power. Having a policy through the "influence trading" method ensures a smooth "criminal business". This is exactly the intention of the criminals, by laundering the illegal "black or dirty income" to secure first economic and then political power, even positions in power. It is well known that money buys political power, and political power "makes" money.

In the money laundering procedure, the perpetrators are constantly improving the ways of realization. In addition to the well-known ones, new ways of money laundering are constantly appearing, and the technical-technological development, as well as the development of the economic and financial relations at the international level have a great contribution to that. One of the ways of money laundering committed within organized crime is a strong link between the criminal organization and individual state or other bodies, whose representatives, using their position, function, reputation and influence, are involved in organizing and conducting illegal activities with the whole legalization of "dirty" money. Criminal organizations have "dirty" money at their disposal and try to smuggle that money into legal economic and financial flows or smuggle it across a border into a foreign country where they can legalize it.

By accepting recommendations from international legal acts and creating a legal system for preventing money laundering involving a number of entities - financial and non-financial institutions that have a legal obligation to identify suspicious financial transactions, financial intelligence administrations that analyze reported suspicious suspicions and legally envisaged - limited transactions and law enforcement agencies that detect crimes that have resulted in illegally obtained returns, the hoop narrows andreduce the chances of easy "infiltration" of criminal money in the legal financial system.

But money launderers are closely monitoring the legislation and are constantly working to find new techniques to launder money. This is helped by other people (professionals) who, by preparing falsified financial documentation or using a welldesigned most appropriate scheme, contribute to the realization of the criminal intent, ie to legalize the "dirty" money. The process of legalization of "dirty" money is also realized through corruption or "bribery" of officials or responsible persons in the entities or persons who perform activities of public interest. Corrupting these individuals enables transactions to be performed in less dubious ways: by splitting transactions, using other people to deposit money into cash accounts, concluding contracts for fictitious loans - long, even in the case of displaying (showing, disposing) "Criminal money" in probate proceedings, where the court does not pay attention to the origin of the money, only registers it as cash of the deceased to be inherited by the heirs it was not even a dubious element that only one of the heirs inherited the money according to the other heirs. 
The approaches to determining the criminal activities that should be subject to the provisions relating to money laundering vary depending on the criteria for determining the term "serious crime". Some countries have decided to enumerate the specific criminal offenses (USA), others have defined the definition based on the amount of the sentence (Austria), in a number of countries it depends on the category of the court that is competent for a particular case. Recently, most countries have decided to accept the definition that covers all types of criminal activity (Belgium, Great Britain, Croatia, Slovenia and other countries, and this group includes and the Republic of N. Macedonia). Some countries have adopted a mixed approach, so that in addition to the listed offenses as predicative, there is a provision that there may be other crimes punishable by at least 5 years in prison and that the crime was committed by an organized criminal group, but that to be in accordance with the Public Prosecutor.

In the Macedonian practice, according to the law enforcement agencies and the Financial Intelligence Unit, money laundering, falsification or destruction of business documentation, abuse of office and authority, illicit drug trafficking and other criminal offenses are most common. Recently, the criminal practice of money laundering acquired by computer financial crime has been enriched.

Money launderers, ie perpetrators of financial crime with elements of tax evasion and money laundering, create types of networks that prevent tax inspectors and law enforcement agencies from obtaining relevant evidence of criminal prosecution of perpetrators. They are built with simple to more complex networks, depending on the power, ability and need for the criminal money that taxpayers have to pay at the expense of the State to avoid the same.

Tax-based liabilities, ie money intended for tax, are redirected to other purposes, most often to new investments, business expansion, etc. The perpetrators of this type of crime are organized and act according to the rules set by the organizer of the criminal group by building a criminal network known as the "tax pyramid". The scheme of the "tax pyramid" is developed by one center, ie the owner of a company that organizes the search of persons on which other companies are registered, with a predetermined criminal idea, through them to turn fictitious documentation in order to show some turnover and payment of tax, to subsequently require a refund of tax from the State. The last company or the last companies in the pyramid withdraw the money in cash and return it to the first company - organizer. It is a criminal scheme of tax evasion of value added tax, which according to the Law is paid by the end users, and the end users instead of paying the tax withdraw the money in cash and thus avoid paying the tax to the state.

Practice shows the existence of organized criminal groups which, according to the involvement of the perpetrators, the place of commission of the crimes and the place of the consequence, in the case of unpaid tax to the State, have the character of international organized criminal groups.

\section{Conclusion}

Money laundering is not a new phenomenon - criminals have always tried to hide the funds that come from their criminal activity. Although this activity was considered a marginal problem for a long time, after the expansion of the drug trade, money laundering became an integral part of any serious criminal activity. 
The proceeds of crime, which are mainly in the form of cash, must be "cleared" so that they can then be used again by criminals. Money laundering involves a series of financial operations (deposits, withdrawals, transfers, etc.) that ultimately result in dirty money being turned into pure money, which can be used for legitimate business activities. In fact, "cleansed" dirty money is "recycled" through legitimate businesses, and from there they enter the legitimate market and spread throughout the economy.

As an international phenomenon that has spread and has been growing steadily in recent years, money laundering can particularly hit transition economies that offer significant opportunities for foreign investment. Financial controls in both the banking and non-banking sectors are often less strict in these countries than in others, making them particularly vulnerable to money laundering operations. Given the various illegal activities, including money laundering by organized crime groups in some of these countries and, in some cases, their alleged infiltration into overall national economies, it is in their vital interest to create and maintain a credible financial a system capable of detecting, preventing and controlling money laundering.

In recent years, the problem of organized crime, which includes money laundering that originates from the replacement or transfer of property in order to conceal or conceal the illegal origin of that property, concealment or disguise of the true nature, source, location, use and transfer of property acquired in an illegal manner, acquisition, possession or use of property by any person who is known or could be known, that such property originates from criminal activities and the commissioning, distribution and use of an offense but acquired money, for performing legally permitted activity or for acquiring property in a lawful manner. As a consequence of the above, income from criminal activity is acquired, which is considered any property or economic gain that is a direct or indirect product of committing a criminal activity. The above actions can be performed by committing, ie not acting, taking, or not taking specific actions.

Money laundering has serious consequences for the international financial system and the financial system of any country, and especially for the economies of developing countries, which can cause destabilization politically.

It follows that money laundering is in fact a legal form of money laundering that originates from criminal activity through the extensive use of the world banking system, making it an international problem, and money laundering is very difficult to detect and prove. The strategy of criminal organizations and to manipulate their illegal actions, through the legitimate financial system, in such a way that the funds derived from these procedures are intended to show that they originate from legitimate sources.

\section{Literature}

1. Andrew Ashworth, Sentencing and Criminal Justice, 5th edn, Cambridge University Press, Cambridge, 2010.

2. Banović, B., Obezbeđenje dokaza krivičnih dela privrednog kriminaliteta, Beograd, 2002.

3. Batkovski, T., Perenje pari - kriminološkokriminalistički aspekti, Bezbednost, 3/96.

4. Bošković, M., Jovičić, D., Kriminalistika Metodika, Banja Luka, 2002. 
5. Brašir, L., Perenjeto pari: amerikanska i makedonska perspektiva, Bezbednost, 4/95.

6. FATF - 1999-2000 Report on Money Laudering Typologies, 10 february 2001.

7. FATF - XII Report on Money Laundering Typologies, (2000-2001), February 2001.

8. Financial Action Task Force on Money Laundering - FATF - Annual Report 19961997, june, 1997.

9. Frčkovski, Lj., Medjunarodna pravna reakcija protiv organiziraniot kriminal, Bebzednost 1/1995.

10. Gilomre, W., Dirty Money, The evaluation on money laundering Counter -measures Council of Europe Press, 1995.

11. Zakon za sprečuvanje na perenje pari i finansiranje na terorizam (Služben vesnik na RM br. 130/2014).

12. Ignjatović, Đ., Sekulić, M., Organizovani kriminalitet, Pravni fakultet Univerziteta $\mathrm{u}$ Beogradu, Beograd, 2010.

13. Kambovski, V., Kazneno pravo: opšt del, Skopje, 2011.

14. Monez Laundering, Guidance For the Financial Sector, Revised and Consolidated June 1997, Joint Monez Laundering Steering Group, Piners Hall 1065'108 Broad Street London.
15. Mršević, Z., Sprečavanje pranja novca merama nacionalnog zakonodavstva, JRKKP, br. 4/92, Beograd, 1992.

16. Medinger, Dž., Vodič za krivični islednici, Data Pons, Skopje, 2009.

17. Nikoloska, S., Perenje pari (Kriminološki, kriminalistički i krivično-pravni aspekti), Univerzitet „Sv. Kliment Ohridski“ - Bitola, Fakultet za bezbednost - Skopje, Skopje, 2015,

18. Nacionalna strategija za borba protiv perenje pari i finansiranje na terorizam, Ministerstvo za finansii, Direkcija za sprečuvanje na perenje pari, Skopje, 2005,

19. Nikolovski, P., Što pretstavuva perenjeto pari, Ekvilibrium br. 13, Ekonomski fakultet, Prilep, 2014.

20. Phil Williams, Ernesto U. Savona, Perenje pari, poim, načini i metodi na izvršuvanje i otkrivanje, Bebzednost, 3/97.

21. Priračnik za sproveduvanje na merki i dejstvija za sprečuvanje na perenje na pari i finansiranje na terorizam od strana na subjektite, Ministerstvo za finansii, Uprava za sprečuvanje na perenje pari i finansiranje terorizam, Skopje, 2010.

22. Služben vesnik na Republika Makedonija broj 04/08 i 57/2010.

23. http://www.fincen.gov/news_room /aml_history.html. 